\title{
Comparison on Economics and Performance of Large Scale PV Power Plants: a Case Study
}

\author{
Rungphet Kongnok, Boonyang Plangklang
}

\begin{abstract}
This paper compares the energy generation of two large-scale PV power plants at a rate of $6 \mathrm{MW}$. Economics and performances are the two main analysis viewpoints for the comparison of the system efficiency and profit of two types $P V$ panel for a service period of twenty-five years. Thin-film and polycrystalline $P V$ power plants have been studied. In the simulation results, three years of actual collected data have been analysed and compared. The $P V$ syst program has been used to simulate the performance ratio (PR) and the energy production. In addition, the net present value (NPV) has been also used to analyse the economic efficiency. The simulation results have showed that in the case of thin-film PV panels, the energy production in the beginning of the year has been higher than the actual collected data. On the other hand, in the case of polycrystalline PV panels, the energy production has been lower than the actual collected data. By the long term economic efficiency, the results have showed that the efficiency of polycrystalline PV panels has been better than the one of thin-film PV panels. Therefore, the obtained results from this work may be used as a guideline for deciding to invest in the PV power plant in the future. Copyright (C) 2021 The Authors.

Published by Praise Worthy Prize S.r.l. This article is open access published under the CC BY-NC-ND license (http://creativecommons.org/licenses/by-nc-nd/3.0/).
\end{abstract}

Keywords: Thin-Film PV Power Plant, Polycrystalline PV Power Plant, Performance Ratio (PR), Net Present Value

\section{Nomenclature}

$a$

AESs

AIM

$b_{o}$

CUF

EVA

$E_{A C}$

$E_{D C}$

$E_{G R I D}$

$E_{P V}$

$E_{Y f}$

$E_{Y r}$

FFANN

$G_{S T C}$

GDP

$i$

$n$

NPV

$P_{C R}$

$P_{\text {max }}$

PEA

$P_{\text {nom }}$

PCC

PR

Array incidence loss

Coating layer of PV panel

Cumulative Unity Factor

Ethylene Vinyl Acetate

$\mathrm{PV}$ installation

Energy of PV generated installation

Gross Domestic Product

Light angle on PV panel

Number of years

Net Present Value

Cable power loss

Performance Ratio
Repayment cash flow per year

Alternating Energy Sources

AC energy of PV generated

DC energy of PV produced per capacity of

AC energy connected to PEA

Energy of PV per capacity of the PV

Energy of PV generate per reference yield capacity of PV installation

Feed Forward Artificial Neural Network Irradiance in STC standard condition

PV module's maximum power

Provincial electricity authority of Thailand

Nominal power loss late rate

Point of Common Coupling

$\begin{array}{ll}R_{\text {array }} & \text { Proportion of } V_{m p} / I_{m p} \text { at STC } \\ \text { REs } & \text { Renewable Energy Sources } \\ \text { SAM } & \text { System Advisor Model } \\ S_{i r r} & \text { Solar irradiation on surface area of PV panel } \\ \text { SPP } & \text { Solar Photovoltaic Plant } \\ \text { SST } & \text { Solid State Transformer } \\ T & \text { Inverter time connect to the grid of PEA } \\ \text { TGVI } & \text { Total global energy investment } \\ U & \text { Thermal loss factor } \\ U_{C} & \text { PV constant element } \\ V_{A C} & \text { AC voltage at inverter output } \\ V_{m p p} & \text { Voltage at maximum power point } \\ V_{o c} & \text { Open circuit voltage of PV panel } \\ \phi & \text { Transformer phase }\end{array}$

\section{Introduction}

The solar energy is known as a source of clean energy.

PV technology is used to convert solar energy into electric energy. Subsequently, it has become widely used worldwide. In Thailand, the government has supported the use of solar energy since 1992. Many PV technologies have been used, including monocrystalline silicon PV, polycrystalline PV and thin-film PV. The study has focused on the performance and the economy of two technologies: the polycrystalline and the thin-film $\mathrm{PV}$, in $6 \mathrm{MW} \mathrm{PV}$ power plant. The study has predicted the investment cost under contract with Thai government 
in 25 years. Many researches have been published and have been involved in evaluating the PV power plant performance in the past. Many researches have considered related factors such as installed location, environment, and PV technologies. There have been case studies on the system design for stand-alone PV with a power size of less than $1 \mathrm{~kW} /$ day. The study result has shown that it could be used for two days on a single charge. This design has been suitable for low-income people and remote area that cannot reach basic electrical systems. Therefore, the use of batteries to store energy could help the system to gain the system reliable [2].

Furthermore, the quality control of solar power using Solid State Transformer (SST) contributes to the stability of the electrical system [3], [4]. The PV systems have been also used to illuminate the roads in order to minimize the costs [5]. The energy storage systems have been used to achieve good performance of the PV power system [6]. The location effect of the PV power plant in a radial distribution system could reduce total power loss by determining the optimal position installation of the PV power plant. The optimum position of the PV power plant has been the length of $67.25 \%$ from the substation.

It could decrease the optimal power loss of the grid [7]. Most of the PV power plants have been installed on the ground and on the rooftop, while some other PV power plants have been installed above water [8], [9].

The potential of the PV floating is different from the PV on-ground type [9]. The energy produced depends on the environmental of PV floating power plant. A study of performance analysis of a $25 \mathrm{MW}$ PV power plant in India from 2015 to 2017 has been simulated using the PVsyst program compared to the calculation with Excel. It has been found out that the solar power plant had a similar decrease in performance in the $74-80 \%$ range and had a Cumulative Utility Factor (CUF) of 16-24\%, respectively [10]. The performance of thin-film PV has been compared with the one of monocrystalline PV panels. It has been found out that performance of thinfilm PV has been better than monocrystalline PV panel [11]. The effect of climate and location has presented the performance of the different PV types. The degradation rate of thin-film PV panel has been low with nearly $0.1 \%$, but the one of polycrystalline panel has been in the range of $-0.67 \%$ to $-0.83 \%$ [12]. The preliminary analysis has shown that the performance of the thin-film PV panels has been higher than the one of the polycrystalline PV. However, it takes up more installation than the monocrystalline and polycrystalline solar panels. For monotype PV panels using the Ethylene-Vinyl Acetate (EVA) coating on cells when considered in dry climates, it has been found out that the performance has decreased by $2.22 \%$ per year. Meanwhile, the PV monotype has reduced the breakdown by $4.57 \%$ per year. It has been better to use a solar panel with EVA for better performances in dry conditions [13]. This solar panels technology approach could make power plants more productive with capacity readiness index indicators from less damaged panels, increasing production opportunities. In this study, the proposed method has been used to compare the power generating value from the real-time measurement and the prototype model from System Advisor Model (SAM) analysis. The results have showed that the actual production value has been higher than the prototype model evaluated value. From the study, it has been found out that the most influencing factor has been the sun's radiation intensity. The use of the model is suitable for the initial estimation of the production capacity [14]. In order to analyze the performance of the PV power plants, it is important to know the capacity of the power plant to assess the potential of the power plant. A research has presented the Feed-Forward Artificial Neural Network (FFANN) with rapid forecasting method, which has been used as the principle for the performance prediction of the PV power plant. The big data has been used to analyze, whilst the result of simulations could predict the capacity of the PV power plant [15]. Previous researches have conducted most of the performance studies of the PV power plants in many conditions [24]. They have been studied under different conditions such as location, environmental factors, delegation factor, and PV panel technologies.

The performance studies are based on the simulation production data and the power generation actual production data. Therefore, there is still a lack of articles on investment time, break-even point, and payback period for the large-scale PV power plant. In this article, these topics are detailed. This article has studied and compared two PV power plant technologies: thin-film PV and the polycrystalline PV. The study results have been described in the next section.

\section{Fundamental Theory of PV}

\section{II.1. Performance of PV Power Plant System}

The performance of PV power plant reference follows ICE standard code IEC 61724 [16]. This can be calculated by Equations (1)-(4):

$$
\begin{gathered}
E_{D C}=\frac{E_{P V}}{E_{P V(\max )}} \\
E_{Y r}=\frac{S_{\text {irr }}}{G_{S T C}} \\
E_{Y f}=\frac{E_{A C}}{E_{P V(\max )}} \\
P R=\frac{E_{D C}}{E_{Y r}}
\end{gathered}
$$

where $E_{D C}$ represents the DC energy of PV produced per capacity of a PV installation $(\mathrm{kWh} / \mathrm{kWp}), E_{P V}$ represents the energy of PV generated (kWh), $E_{P V(\max )}$ represents the maximum capacity of a PV installation $(\mathrm{kWp}), E_{Y r}$ 
represents the energy of PV generate per reference yield capacity of a PV installation $(\mathrm{kWh} / \mathrm{kWp}), S_{\text {irr }}$ represents the solar irradiation on the surface area of PV panel $\left(\mathrm{kW} / \mathrm{m}^{2}\right), G_{S T C}$ represents the irradiance in STC standard condition (AM $1.5,1 \mathrm{kWp} / \mathrm{m}^{2}$ at $25^{\circ} \mathrm{C}$ ), $E_{Y f}$ represents the energy of PV per capacity of the PV installation $(\mathrm{kWh} / \mathrm{kWp})$ and $E_{P V}$ represents an AC energy of PV generated $(\mathrm{kWh})$.

\section{II.2. Loss Effect in PV Power Plant}

The energy generation from the PV power plant is divided into two parts: natural effects and the PV system installation. The natural effects are the position of the sun irradiation and the environment. The PV system installed consists of a PV module, an inverter, a transformer, a cable, an installation method, etc. The energy from the PV power plant has been connected to the primary grid and it has been calculated by Equation (5). This energy is the benefit of the power plant:

$$
E_{G R I D}=V_{A C} I_{A C} T
$$

where $E_{\text {GRID }}$ represents the AC energy connected to the main grid $(\mathrm{kWh}), V_{A C}$ represents the $\mathrm{AC}$ voltage at inverter output $(\mathrm{V}), I_{A C}$ represents the $\mathrm{AC}$ at inverter output (A), and $T$ represents the time of inverter connected to the main grid (hr). The PV power plant has many losses, which affect the generation of energy. They are the PV heat loss factor, the ohmic loss, and the array incidence loss. The loss effects are shown in Equations (6)-(8). The PV heat loss factor is the loss of PV array thermal, as shown in Equation (6):

$$
U=U_{C}+U_{V} v
$$

where $U$ represents the thermal loss factor $\left(\mathrm{W} / \mathrm{m}^{2} \mathrm{k}\right), U_{C}$ represents the PV constant element, and $v$ represents the wind speed $(\mathrm{m} / \mathrm{s})$. The ohmic loss factor is the loss of cable installation in the PV power plant. The ohmic loss is considered under the standard condition at $1000 \mathrm{~W} / \mathrm{m}^{2}$ and temperature $25{ }^{\circ} \mathrm{C}$. The proportion of the cable power loss is caused by the cable resistance $\left(P_{C R}\right)$ with nominal power loss late rate $\left(P_{n o m}\right)$. The loss is shown in Eqs. (7) and (8):

$$
\begin{gathered}
P_{C R}=R_{\text {Cable }} I_{S C}^{2} \\
P_{\text {nom }}=R_{\text {array }} I_{S C}^{2}
\end{gathered}
$$

where $I_{s c}$ represents the short circuit current of PV panel (A), $R_{\text {cable }}$ represents the total resistance of cable used $(\Omega), V_{m p}$ represents the voltage at maximum power point of PV panel (V), and $R_{\text {array }}$ represents the proportion of $V_{m p} / I_{m p}$ at STC $(\Omega)$. The array incidence loss (AIM) is the light effect from the sun angle in a day. AIM's effect consists of solar irradiation transferred, and the reflection between two translucent materials followed by the theory of the Fresnel's law. The AIM can be computed by Equation (9):

$$
E_{I A M}=1-b_{o}\left(\frac{1}{\cos (i)}-1\right)
$$

where $i$ represents the light angle on the PV panel, $b_{o}$ represents the coating layer of the PV panel. In addition to the preceding, there are other losses, such as the PV module efficiency, the PV power plant location, the season, the number of days, the raining, loss from the inverter, etc.

\section{II.3. Annuity Method Theory}

The annuity method is the basis of cash flow calculations.

This method commonly uses two forms: static method and dynamic method. The dynamic annuity method can show cash flow more than the static annuity one. The electrical system applies the annuity method for calculation annuity cost by series repayment. The result data of calculation is matched with the average of annuity cash flow:

$$
a=N P V \frac{\left[i(1+i)^{n}\right]}{\left[(1+i)^{n}-1\right]}
$$

where $a$ represents the repayment cash flow per year, $N P V$ represents the net present value, $i$ represents the interest, and $n$ represents the number of years.

\section{Methodology}

Five topics in the methodology have been presented.

There are PV power plant locations, the information of equipment in PV power plant, the single line diagram, the detail of the PV power plant and the economics data of the PV power plant, respectively.

\section{III.1. Location of PV Power Plant}

The PV power plant site has been located at Hua Wa subdistrict, Si Maha Phot District, Prachin Buri province, the central part of Thailand. It is located on latitude $13.89 \mathrm{~N}$ and longitude $101.45 \mathrm{E}$.

The thin-film PV type power plant and the polycrystalline PV type power plant have been used for the cases studied. Both types have the same size of 6 MWp.

\section{III.2. Study on Equipment Installation}

The main equipment used in the PV power plant consists of a cable, 125, 130, $310 \mathrm{Wp} \mathrm{PV} \mathrm{panels,} \mathrm{an}$ 
inverter, and a transformer.

The device has the following detail, as shown in Tables II-IV. These equipment details have been used for the cost estimation of the PV power plant. Table I shows the current rate and the method used in PV power plant capacity. Table II shows the characteristics of $125 \mathrm{Wp}$ thin-film PV panels, and Table III shows the characteristic of the $130 \mathrm{Wp}$ thin-film PV panels used in the PV power plant.

Table IV is the characteristic of $310 \mathrm{Wp}$ polycrystalline PV panels used in the PV power plant.

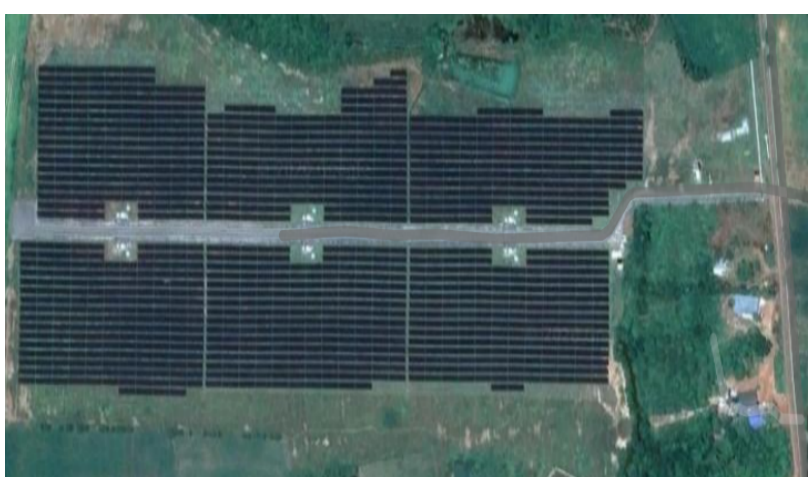

Fig. 1. PV power plant [17]

TABLE I

Characteristics Of XLPE High Voltage CABLe [18]

\begin{tabular}{|c|c|c|}
\hline $\begin{array}{l}\text { Surface area } \\
\qquad\left(\mathrm{mm}^{2}\right)\end{array}$ & $\begin{array}{l}\text { The current rate of } 2 \\
\text { conductors: single and } \\
\text { multi-core (A) }\end{array}$ & $\begin{array}{l}\text { The current rate of } 3 \\
\text { conductors: single and multi- } \\
\text { core (A) }\end{array}$ \\
\hline No.- 6 & 54 & 47 \\
\hline No.- 10 & 71 & 63 \\
\hline No.- 35 & 150 & 132 \\
\hline No.- 95 & 271 & 238 \\
\hline No.- 150 & 355 & 312 \\
\hline No.- 300 & 543 & 475 \\
\hline
\end{tabular}

TABLE II

ChARACTERISTICS OF THIN-FILM PV PANEL OF $125 \mathrm{Wp}$ (STC) [19]

\begin{tabular}{cc}
\hline \hline Thin-film characteristics details & Value \\
\hline PV module's maximum power $\left(P_{\max }\right)$ & $125 \mathrm{Wp}$ \\
Open circuit voltage of PV panel $\left(V_{o c}\right)$ & $59.7 \mathrm{~V}$ \\
Short - circuit current of PV panel $\left(I_{s c}\right)$ & $3.37 \mathrm{~A}$ \\
The voltage at maximum power point $\left(V_{m p p}\right)$ & $45.5 \mathrm{~V}$ \\
Current at maximum power point $\left(I_{m p p}\right)$ & 2.75 \\
Power effect compassion with temperature $\left(\% /{ }^{\circ} \mathrm{C}\right)$ & -0.24 \\
The efficiency of PV panel $(\%)$ & 8.90 \\
PV panel dimension $(\mathrm{L} \times \mathrm{W} \times \mathrm{H}, \mathrm{mm})$ & $1402 \times 1001 \times 6.7$ \\
PV panel weigh $(\mathrm{kg})$ & 24 \\
\hline
\end{tabular}

TABLE III

Characteristics Of Thin-Film PV Panel OF $130 \mathrm{Wp}$ (STC) [19]

\begin{tabular}{cc}
\hline \hline Thin-film characteristics details & Value \\
\hline PV module maximum power $\left(P_{\max }\right)$ & $130 \mathrm{Wp}$ \\
Open circuit voltage of PV panel $\left(V_{o c}\right)$ & $60.4 \mathrm{~V}$ \\
Short - circuit current of PV panel $\left(I_{s c}\right)$ & $3.41 \mathrm{~A}$ \\
The voltage at maximum power point $\left(V_{m p p}\right)$ & $46.1 \mathrm{~V}$ \\
Current at maximum power point $\left(I_{m p p}\right)$ & $2.82 \mathrm{~A}$ \\
Power effect compassion with temperature $\left(\% /{ }^{\circ} \mathrm{C}\right)$ & -0.24 \\
The efficiency of PV panel $(\%)$ & 9.30 \\
PV panel dimension $(\mathrm{L} \times \mathrm{W} \times \mathrm{H}, \mathrm{mm})$ & $1402 \times 1001 \times 6.7$ \\
PV panel weight $(\mathrm{kg})$ & 24 \\
\hline \hline
\end{tabular}

TABLE IV

CHARACTERISTICS OF POLYCRYSTALLINE PV PANEL OF $310 \mathrm{Wp}$ (STC) [20]

\begin{tabular}{cc}
\hline \hline Polycrystalline characteristics details & Value \\
PV module's maximum power $\left(P_{\max }\right)$ & $310 \mathrm{Wp}$ \\
Open circuit voltage of PV panel's $\left(V_{o c}\right)$ & $45.50 \mathrm{~V}$ \\
Short - circuit current of PV panel $\left(I_{s c}\right)$ & $8.85 \mathrm{~A}$ \\
The voltage at maximum power point $\left(V_{m p p}\right)$ & $46.1 \mathrm{~V}$ \\
Current at maximum power point $\left(I_{m p p}\right)$ & $8.38 \mathrm{~A}$ \\
Power effect compassion with temperature $\left(\% /{ }^{\circ} \mathrm{C}\right)$ & -0.41 \\
The efficiency of module $\mathrm{PV}(\%)$ & 15.99 \\
PV panel dimension $(\mathrm{L} \times \mathrm{W} \times \mathrm{H}, \mathrm{mm})$ & $1596 \times 991 \times 45$ \\
PV panel weight $(\mathrm{kg})$ & 26 \\
\hline \hline
\end{tabular}

Table V shows the characteristic of the inverter size $500 \mathrm{kWp}$. Table VI shows the characteristic of the transformer size $1,250 \mathrm{kVA}$.

\section{III.3. Single Line Diagram}

The single line diagram shows the position of the equipment installation in the PV power plant. The main equipment consists of a PV panel, an inverter transformer, and other equipment. The PV power plant's energy is connected to PEA at the Point of Common Coupling (PPC). Two PV power plants studied have been located in the same area. The irradiation average has been $17.80 \mathrm{MJ} / \mathrm{m}^{2}$. The thin-film power plant used has been 24,000 PV panels, $125 \mathrm{Wp}$ and 23,040 PV panels, and $130 \mathrm{Wp}$.

TABLE V

INVERTER CHARACTERISTICS OF $500 \mathrm{MX}$ [21]

\begin{tabular}{cc}
\hline \hline Inverter characteristics detail & Value \\
DC input & \\
\hline Rated maximum voltage $\left(V_{\max }\right)$ & 1000 \\
Rate minimum operation input voltage $\left(V_{\min }\right)$ & $460-500$ \\
MPP range of voltage operation $(\mathrm{V})$ & $460-850$ \\
Total DC input (PCS) & $6-8$ \\
Input current maximum rate (A) & 1220 \\
Short circuit current maximum rate $(\mathrm{A})$ & 1460 \\
\hline Output power & $550 \mathrm{kVA} @ 50^{\circ} \mathrm{C}$, \\
Maximum current (A) & $500 \mathrm{kVA} @ 55^{\circ} \mathrm{C}$ \\
Nominal voltage (V) & 1008 \\
Nominal frequency/Grid frequency $\left(H_{z}\right)$ & 515 \\
Total harmonic distortion (THD, $\%)$ & $63($ at nominal power) \\
Nominal power factor /adjust table power factor & $>0.99 / 0.81$ leading -0.8 \\
Transformer feed-in/Connection phases & lagging \\
Maximum efficiency standard /European $(\%)$ & $3 / 3$ \\
\hline \hline
\end{tabular}

TABLE VI

Characteristics OF STEP-UP TRANSFORMER WiTH SIZE OF 1,250 kVA [22]

\begin{tabular}{cc}
\hline \hline Transformer characteristics detail & Value \\
Transformer rate power (kVA) & $1250(625 / 625)$ \\
Transformer frequency (Hz) & 50 \\
Primary Voltage (V) & $22000 \mathrm{~V}$ \\
Secondary Voltage $(\mathrm{V})$ & $315 / 315 \mathrm{~V}$ \\
Maximum short circuit rate $(\mathrm{kA})$ & $38.18 \mathrm{kA}$ \\
Transformer phase $(\phi)$ & 3 \\
Transformer tapping & $\pm 2 \times 2.5 \%$ \\
Vector group & Dy11y11 \\
Noise level & $\leq 59 \mathrm{~dB}$ \\
No load loss (@1250kVA, $\left.75^{\circ} \mathrm{C}\right)$ & $0.95 \mathrm{~kW}$ \\
On load loss (@625VA, $\left.75^{\circ} \mathrm{C}\right)$ & $4.75 \mathrm{~kW}$ \\
Transformer step & 5 \\
\hline \hline
\end{tabular}




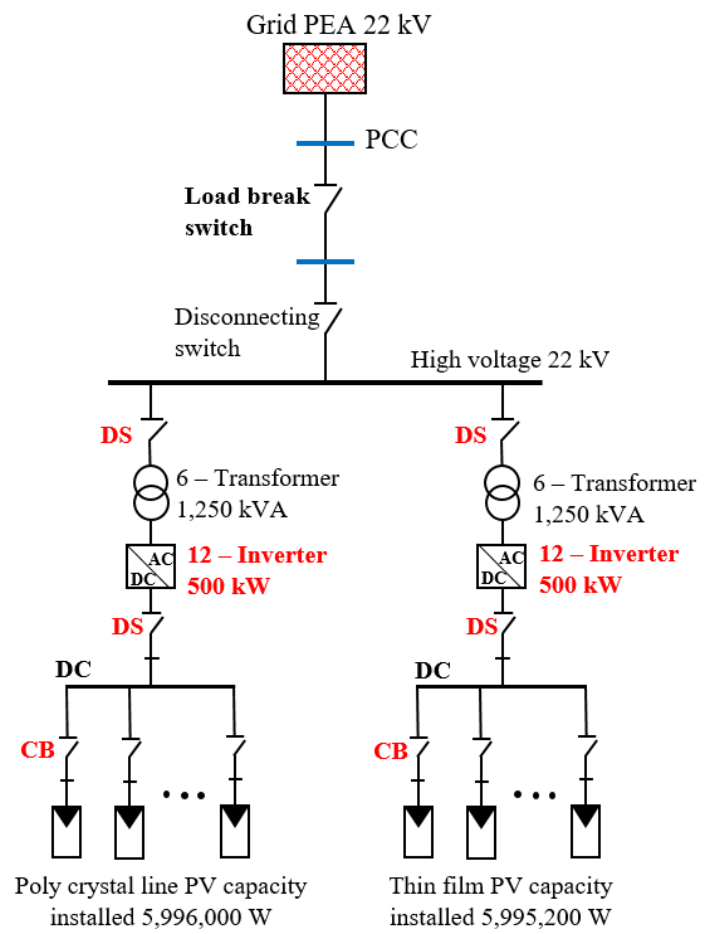

Fig. 2. Single diagram of PV power plant

The total capacity of the power plant has been $5,995,200 \mathrm{Wp}$. The power plant area has been $66,083 \mathrm{~m}^{2}$.

The polycrystalline PV power plant used has been 19,341 PV panel, $310 \mathrm{Wp}$. The total capacity of the power plant has been $5,996,000 \mathrm{Wp}$. The power plant area has been covered by $34,491 \mathrm{~m}^{2}$.

\section{III.4. Detail of PV Power Plant}

The installation cost is the total cost of the PV power plant. The detail of the installation cost is shown in Table VII. Table VII shows the detail of the installation cost of the PV power plant. The thin-film PV power plant has a total installation cost of 7,610,466 \$, while the polycrystalline PV power plant has a total installation cost of $8,022,077 \$$. The total installation cost of a thinfilm PV power plant is less than the one of polycrystalline PV power plant, by about $411,610 \$$, on $5.131 \%$.

\section{III.5. The Economic Data of PV Power Plant}

This study has used the PV power plant data from the first year of the PV power plant operation from 2016 to 2018. The data show the performance and the energy degradation of the PV power plant. The price of energy for sale to PEA is $0.188 \$$ per $1 \mathrm{kWh}$, the period for sale is 25 years.

\section{Results and Discussion}

The energy generation from PV power plants is shown in Table VIII from the year 2016 to 2018 . The data have been compared with the energy generation, which has been estimated using the PVsyst simulation program [23]. Table VIII compares the actual total energy generation results of the thin-film PV power plant and polycrystalline PV power plant with the PVsyst simulation program simulation result. The energy of the thin-film PV generation in 2016 was $9,718,327 \mathrm{kWh}$. It is more than the energy from simulation by $2.85 \%$. The energy generation of the ploy crystalline PV power plant was $9,088,734 \mathrm{kWh}$ in 2016 . It is lower than the energy from the simulation by $1.57 \%$.

Moreover, the comparison of the energy for each type of PV power plant in 2016 to 2018 is shown in Table VIII. For the thin-film PV power plant, the energy generation has decreased by $1.30 \%$ and $3.31 \%$ in 2017 and 2018, respectively. In addition, for the power generation of polycrystalline PV power plants, the energy generation has decreased by $2.77 \%$ and $4.38 \%$ in 2017 and 2018, respectively.

The PV power plant installation cost has been calculated by Equation (5) for finding the NPV of the power plant. It is equal to $8 \%$ and the period is 25 years.

Fig. 3 shows the cash flow received comparison of thin-film PV power plant and polycrystalline PV power plant. The first one has the maximum cash flow received of $1,645,947 \$$, and the minimum cash flow received of $1,463,064 \$$.

The average cash flow received is $1,536,218 \$$. The polycrystalline PV power plant has the maximum cash flow received of $1,659,041 \$$, and the minimum cash flow received of $1,368,281 \$$. The average cash flow received is $1,513,469 \$$.

The thin-film PV power plant has an average cash flow higher than the polycrystalline PV power plant by $1.48 \%$.

TABLE VII

INSTALLATION COST OF PV POWER PLANT

\begin{tabular}{cccc}
\hline \hline \multirow{2}{*}{ Cost detail } & \multicolumn{2}{c}{ PV system price $(\$)$} & \multirow{2}{*}{ Lifetime (Y) } \\
& Thin-film & Polycrystalline & \\
\hline Land & 664,960 & 412,275 & 25 \\
Road \& wall & 575,190 & 365,063 & 25 \\
Wire and tube & 498,720 & 398,976 & 25 \\
PV structure & $3,324,800$ & $4,488,480$ & 25 \\
Inverter and connection & 631,712 & 598,464 & 10 \\
box & & & \\
Transformer and & 199,488 & 199,488 & 10 \\
accessories & 398,976 & 398,976 & 10 \\
Water & 31,586 & 24,936 & 25 \\
Lightning protection & 93,094 & 79,795 & 3 \\
CCTV system & 28,261 & 28,261 & 3 \\
Monitoring system & 930,944 & 797,952 & 25 \\
Installation cost & 216,112 & 216,112 & 1 \\
Operation \& maintenance & 25,12 & 1 \\
Spare part & 16,624 & 13,299 & \\
Total cost & $\mathbf{7 , 6 1 0 , 4 6 6}$ & $\mathbf{8 , 0 2 2 , 0 7 7}$ & \\
\hline \hline
\end{tabular}

TABLE VIII

ENERGY GENERATION FROM PV POWER PLANT

\begin{tabular}{ccccc}
\hline \hline \multirow{2}{*}{ Since } & \multicolumn{2}{c}{ Simulation (kWh) } & \multicolumn{2}{c}{ Real energy (kWh) } \\
& Thin-film PV & Poly crystalline & Thin-film PV Poly crystalline \\
\hline 2016 & $9,441,675$ & $9,163,153$ & $9,718,327$ & $9,088,734$ \\
2017 & - & - & $9,592,114$ & $8,791,575$ \\
2018 & - & - & $9,396,797$ & $8,675,527$ \\
\hline \hline
\end{tabular}


TABLE IX

CASh Flow Comparison OF The Thin-Film PV Power Plant Between PVsyst Simulation With Installation PRediction

\begin{tabular}{|c|c|c|c|c|c|c|c|}
\hline \multirow[b]{2}{*}{ Year } & \multirow[b]{2}{*}{ Efficiency (\%) } & \multicolumn{2}{|c|}{ Thin-Film PV Panel } & \multirow[b]{2}{*}{ Year } & \multirow[b]{2}{*}{ Efficiency (\%) } & \multicolumn{2}{|c|}{ Thin-Film PV Panel } \\
\hline & & $\begin{array}{c}\text { PVsyst cash flow } \\
\text { receive }(\$)\end{array}$ & $\begin{array}{c}\text { Installation cash flow } \\
\text { receive }(\$)\end{array}$ & & & $\begin{array}{l}\text { PVsyst cash flow } \\
\text { receive }(\$)\end{array}$ & $\begin{array}{c}\text { Installation cash flow } \\
\text { receive }(\$)\end{array}$ \\
\hline 0 & $100 \%$ & 0 & 0 & 13 & $80 \%$ & $1,421,415$ & $1,463,064$ \\
\hline 1 & $90 \%$ & $1,599,092$ & $1,645,947$ & 14 & $80 \%$ & $1,421,415$ & $1,463,064$ \\
\hline 2 & $90 \%$ & $1,599,092$ & $1,645,947$ & 15 & $80 \%$ & $1,421,415$ & $1,463,064$ \\
\hline 3 & $90 \%$ & $1,599,092$ & $1,645,947$ & 16 & $80 \%$ & $1,421,415$ & $1,463,064$ \\
\hline 4 & $90 \%$ & $1,599,092$ & $1,645,947$ & 17 & $80 \%$ & $1,421,415$ & $1,463,064$ \\
\hline 5 & $90 \%$ & $1,599,092$ & $1,645,947$ & 18 & $80 \%$ & $1,421,415$ & $1,463,064$ \\
\hline 6 & $90 \%$ & $1,599,092$ & $1,645,947$ & 19 & $80 \%$ & $1,421,415$ & $1,463,064$ \\
\hline 7 & $90 \%$ & $1,599,092$ & $1,645,947$ & 20 & $80 \%$ & $1,421,415$ & $1,463,064$ \\
\hline 8 & $90 \%$ & $1,599,092$ & $1,645,947$ & 21 & $80 \%$ & $1,421,415$ & $1,463,064$ \\
\hline 9 & $90 \%$ & $1,599,092$ & $1,645,947$ & 22 & $80 \%$ & $1,421,415$ & $1,463,064$ \\
\hline 10 & $90 \%$ & $1,599,092$ & $1,645,947$ & 23 & $80 \%$ & $1,421,415$ & $1,463,064$ \\
\hline 11 & $80 \%$ & $1,421,415$ & $1,463,064$ & 24 & $80 \%$ & $1,421,415$ & $1,463,064$ \\
\hline 12 & $80 \%$ & $1,421,415$ & $1,463,064$ & 25 & $80 \%$ & $1,421,415$ & $1,463,064$ \\
\hline
\end{tabular}

TABLE $X$

Cash Flow COMParison Of The Polycrystalline PV Power Plant Between PVSyst Simulation With InStallation Prediction Polycrystalline PV Panel

Polycrystalline PV Panel

\begin{tabular}{|c|c|c|c|c|c|c|c|}
\hline \multirow[b]{2}{*}{ Year } & \multicolumn{4}{|c|}{ Polycrystalline PV Panel } & & \multicolumn{2}{|c|}{ Polycrystalline PV Panel } \\
\hline & Efficiency $(\%)$ & $\begin{array}{l}\text { PVsyst cash flow } \\
\text { receive }(\$)\end{array}$ & $\begin{array}{c}\text { Installation cash flow } \\
\text { receive }(\$)\end{array}$ & Year & Efficiency $(\%)$ & $\begin{array}{l}\text { PVsyst cash flow } \\
\text { receive }(\$)\end{array}$ & $\begin{array}{l}\text { Installation cash flow } \\
\text { receive }(\$)\end{array}$ \\
\hline 0 & $100 \%$ & 0 & 0 & 13 & $89 \%$ & $1,526,055$ & $1,513,661$ \\
\hline 1 & $97 \%$ & $1,672,625$ & $1,659,041$ & 14 & $88 \%$ & $1,513,812$ & $1,501,517$ \\
\hline 2 & $96 \%$ & $1,660,382$ & $1,646,897$ & 15 & $87 \%$ & $1,501,569$ & $1,489,374$ \\
\hline 3 & $96 \%$ & $1,648,139$ & $1,634,754$ & 16 & $86 \%$ & $1,489,499$ & $1,477,401$ \\
\hline 4 & $95 \%$ & $1,636,069$ & $1,622,781$ & 17 & $86 \%$ & $1,477,256$ & $1,465,258$ \\
\hline 5 & $94 \%$ & $1,623,826$ & $1,610,638$ & 18 & $85 \%$ & $1,465,013$ & $1,453,114$ \\
\hline 6 & $93 \%$ & $1,611,583$ & $1,598,494$ & 19 & $84 \%$ & $1,452,770$ & $1,440,971$ \\
\hline 7 & $93 \%$ & $1,599,340$ & $1,586,351$ & 20 & $84 \%$ & $1,440,527$ & $1,428,827$ \\
\hline 8 & $92 \%$ & $1,587,097$ & $1,574,207$ & 21 & $83 \%$ & $1,428,284$ & $1,416,684$ \\
\hline 9 & $91 \%$ & $1,574,854$ & $1,562,064$ & 22 & $82 \%$ & $1,416,213$ & $1,404,711$ \\
\hline 10 & $90 \%$ & $1,557,611$ & $1,544,960$ & 23 & $81 \%$ & $1,403,971$ & $1,392,568$ \\
\hline 11 & $90 \%$ & $1,550,541$ & $1,537,948$ & 24 & $81 \%$ & $1,391,728$ & $1,380,424$ \\
\hline 12 & $89 \%$ & $1,538,298$ & $1,525,804$ & 25 & $80 \%$ & $1,379,485$ & $1,368,281$ \\
\hline
\end{tabular}

TABLE XI

CASH Flow USing NPV Calculation OF The PV POWER Plant Between PVSYst Simulation On 25 Years

\begin{tabular}{|c|c|c|c|c|c|c|c|c|c|}
\hline \multirow[b]{2}{*}{ Year } & \multicolumn{2}{|c|}{ "Thin-film } & \multicolumn{2}{|c|}{ Polycrystalline } & \multirow[b]{2}{*}{ Year } & \multicolumn{2}{|c|}{ "Thin-film } & \multicolumn{2}{|c|}{ Polycrystalline } \\
\hline & $\begin{array}{c}\text { PVsyst } \\
\text { NPV (\$) }\end{array}$ & $\begin{array}{c}\text { Install. } \\
\text { NPV (\$) }\end{array}$ & $\begin{array}{c}\text { PVsyst } \\
\text { NPV (\$) }\end{array}$ & $\begin{array}{c}\text { Install. } \\
\text { NPV (\$) }\end{array}$ & & $\begin{array}{c}\text { PVsyst } \\
\text { NPV (\$) }\end{array}$ & $\begin{array}{c}\text { Install. } \\
\text { NPV (\$) }\end{array}$ & $\begin{array}{l}\text { PVsyst } \\
\text { NPV }(\$)\end{array}$ & $\begin{array}{l}\text { Install. } \\
\text { NPV (\$) }\end{array}$ \\
\hline 0 & $-7,610,466$ & $-7,610,466$ & $-8,022,077$ & $-8,022,077$ & 13 & 428,521 & 443,835 & 482,890 & 478,333 \\
\hline 1 & $1,243,595$ & $1,286,979$ & $1,351,702$ & $1,339,124$ & 14 & 396,774 & 410,954 & 442,947 & 438,761 \\
\hline 2 & $1,151,477$ & $1,191,648$ & $1,241,079$ & $1,229,518$ & 15 & 367,381 & 380,510 & 406,274 & 402,429 \\
\hline 3 & $1,066,192$ & $1,103,388$ & $1,139,440$ & $1,128,814$ & 16 & 304,267 & 316,424 & 344,520 & 340,989 \\
\hline 4 & 987,198 & $1,021,637$ & $1,046,146$ & $1,036,379$ & 17 & 314,974 & 326,231 & 341,748 & 338,506 \\
\hline 5 & 914,097 & 945,986 & 960,348 & 951,372 & 18 & 291,643 & 302,066 & 313,370 & 310,392 \\
\hline 6 & 768,835 & 798,362 & 820,705 & 812,457 & 19 & 270,039 & 279,689 & 287,319 & 284,585 \\
\hline 7 & 783,687 & 811,027 & 809,052 & 801,473 & 20 & 250,033 & 258,969 & 263,407 & 260,897 \\
\hline 8 & 725,638 & 750,952 & 742,509 & 735,545 & 21 & 28,744 & 37,018 & 57,849 & 55,545 \\
\hline 9 & 671,877 & 695,317 & 681,374 & 674,976 & 22 & 214,367 & 222,028 & 221,360 & 219,245 \\
\hline 10 & 622,114 & 643,818 & 622,921 & 617,061 & 23 & 198,485 & 205,579 & 202,875 & 200,933 \\
\hline 11 & 62,057 & 79,920 & 177,329 & 171,928 & 24 & 183,783 & 190,351 & 185,918 & 184,135 \\
\hline 12 & 462,793 & 479,332 & 526,372 & 521,411 & 25 & 170,169 & 176,251 & 170,358 & 168,722 \\
\hline
\end{tabular}

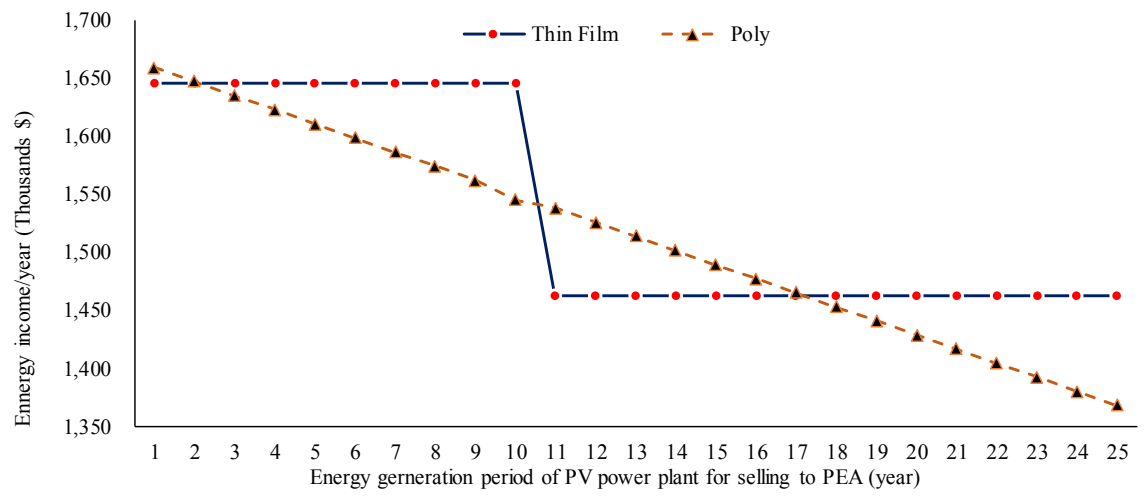

Fig. 3. Cash flow comparisons of thin-film PV and polycrystalline PV 


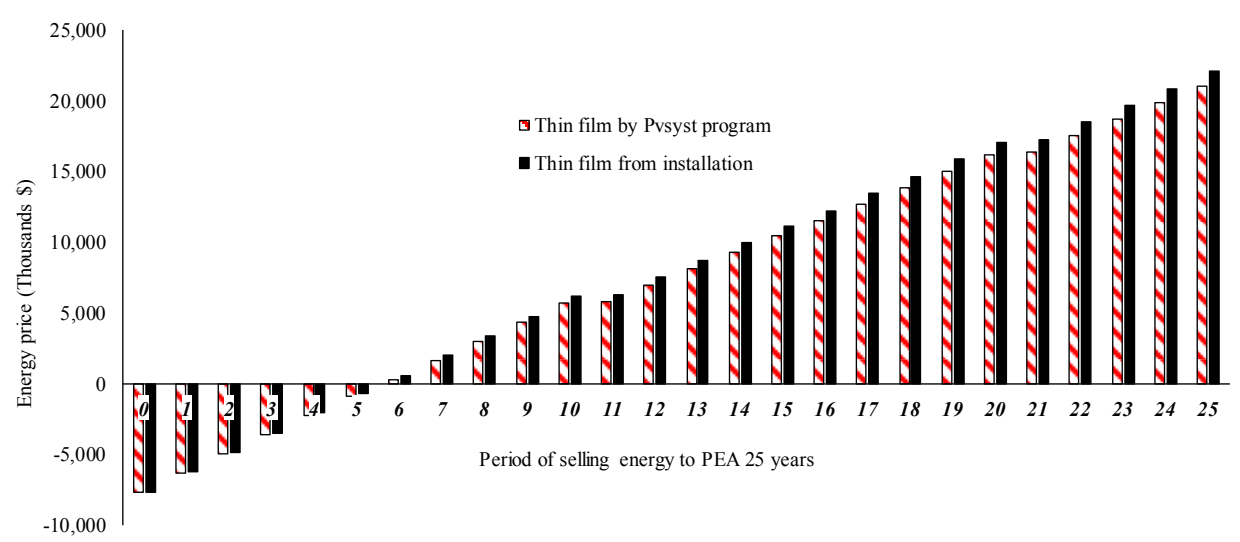

Fig. 4. Cash flow of thin-film PV power plant using NPV calculation by the PVsyst program calculation

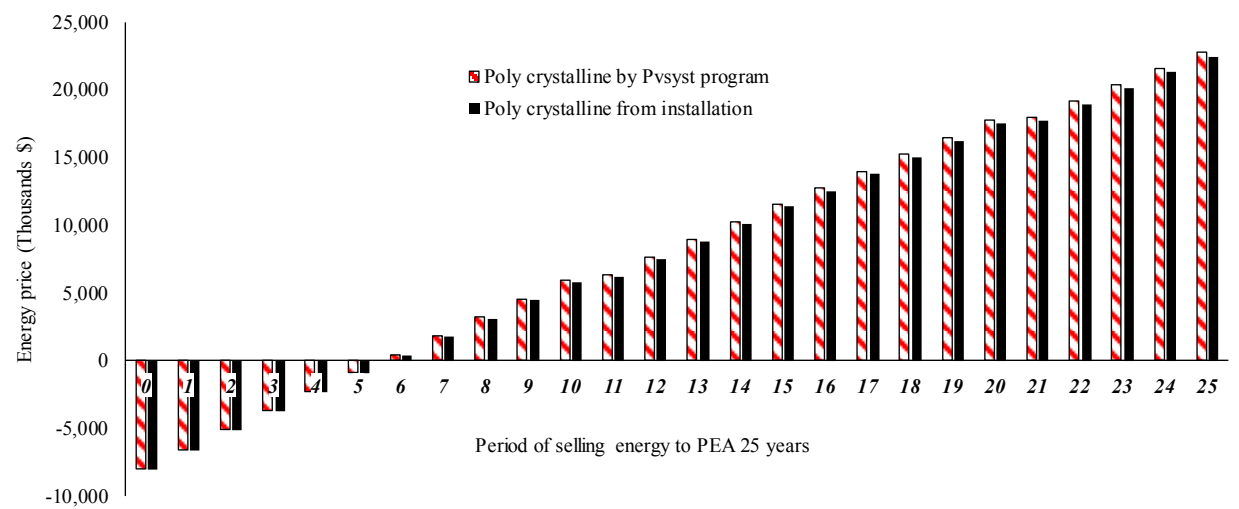

Fig. 5. The cash flow of polycrystalline PV power plant using NPV calculated by the PVsyst program calculation

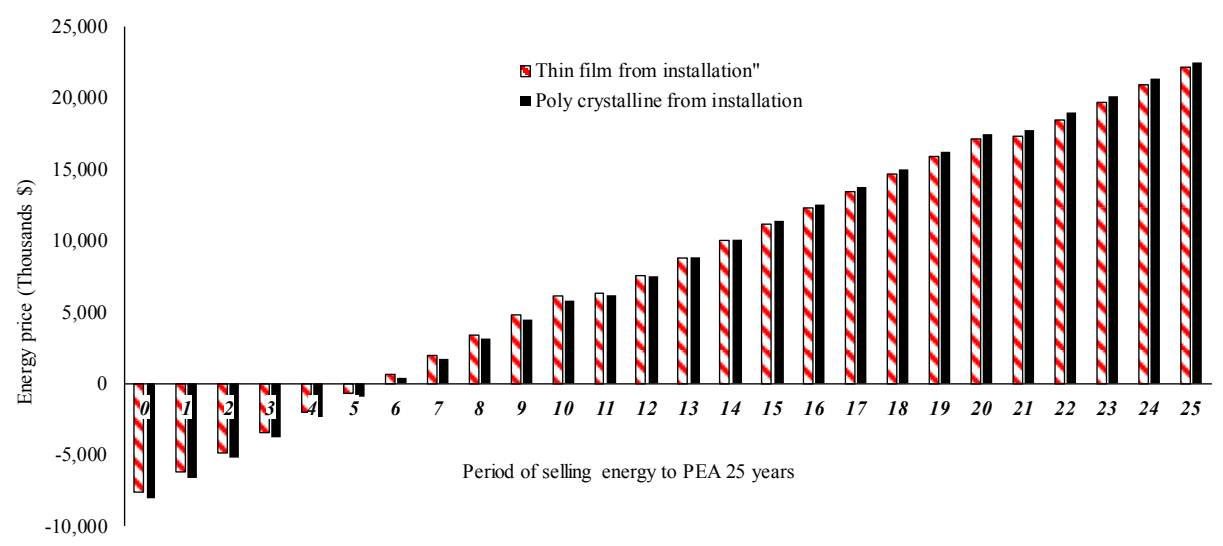

Fig. 6. The cash flow of the thin-film and polycrystalline PV power plant using NPV calculated by real data installation

Fig. 4 shows the comparison between the actual database and the calculation by PVsyst program simulation using the NPV calculation method. The figure shows that the energy from the program simulation is lower than the base of actual data.

The payback period time in Fig. 4 has been started from the sixth year ext.

Fig. 5 shows the same result, but the difference is that the polycrystalline has the cash flow of the NPV. The NPV calculation of the PVsyst program simulation is more than the actual database of the polycrystalline PV installation. The payback period time is shown in Fig. 5, which has started from the sixth year are same that.
Fig. 6 shows the cash flow comparison of thin-film PV power plant and polycrystalline PV power plant using NPV calculation following Equation (10). For cash flow comparison of the thin-film PV and the polycrystalline PV installation, the result shows that the polycrystalline PV cash flow is higher than the thin-film PV power plant. The payback period time is in the sixth years too.

Fig. 7 shows the PV performance of the thin-film PV power plant and the polycrystalline PV power plant. The thin-film PV power plant performance has begun in the first year at a constant rate of $90 \%$ through the $10^{\text {th }}$ year. It decreases with a constant rate of $80 \%$ after operating the power plant for 11 years. 
TABLE XII

PERFORMANCE PERCENTAGE OF THIN-FILM PV AND POLYCRYSTALLINE PV POWER PLANT

\begin{tabular}{|c|c|c|c|c|c|}
\hline Year & Thin-film & Polycrystalline & year & Thin-film & Polycrystalline \\
\hline 0 & $100 \%$ & $100 \%$ & 13 & $80 \%$ & $88.50 \%$ \\
\hline 1 & $90 \%$ & $97 \%$ & 14 & $80 \%$ & $87.79 \%$ \\
\hline 2 & $90 \%$ & $96.29 \%$ & 15 & $80 \%$ & $87.08 \%$ \\
\hline 3 & $90 \%$ & $95.58 \%$ & 16 & $80 \%$ & $86.38 \%$ \\
\hline 4 & $90 \%$ & $94.88 \%$ & 17 & $80 \%$ & $85.67 \%$ \\
\hline 5 & $90 \%$ & $94.17 \%$ & 18 & $80 \%$ & $84.96 \%$ \\
\hline 6 & $90 \%$ & $93.46 \%$ & 19 & $80 \%$ & $84.25 \%$ \\
\hline 7 & $90 \%$ & $92.75 \%$ & 20 & $80 \%$ & $83.54 \%$ \\
\hline 8 & $90 \%$ & $92.04 \%$ & 21 & $80 \%$ & $82.83 \%$ \\
\hline 9 & $90 \%$ & $91.33 \%$ & 22 & $80 \%$ & $82.13 \%$ \\
\hline 10 & $90 \%$ & $90.33 \%$ & 23 & $80 \%$ & $81.42 \%$ \\
\hline 11 & $80 \%$ & $89.92 \%$ & 24 & $80 \%$ & $80.71 \%$ \\
\hline 12 & $80 \%$ & $89.21 \%$ & 25 & $80 \%$ & $80.00 \%$ \\
\hline
\end{tabular}

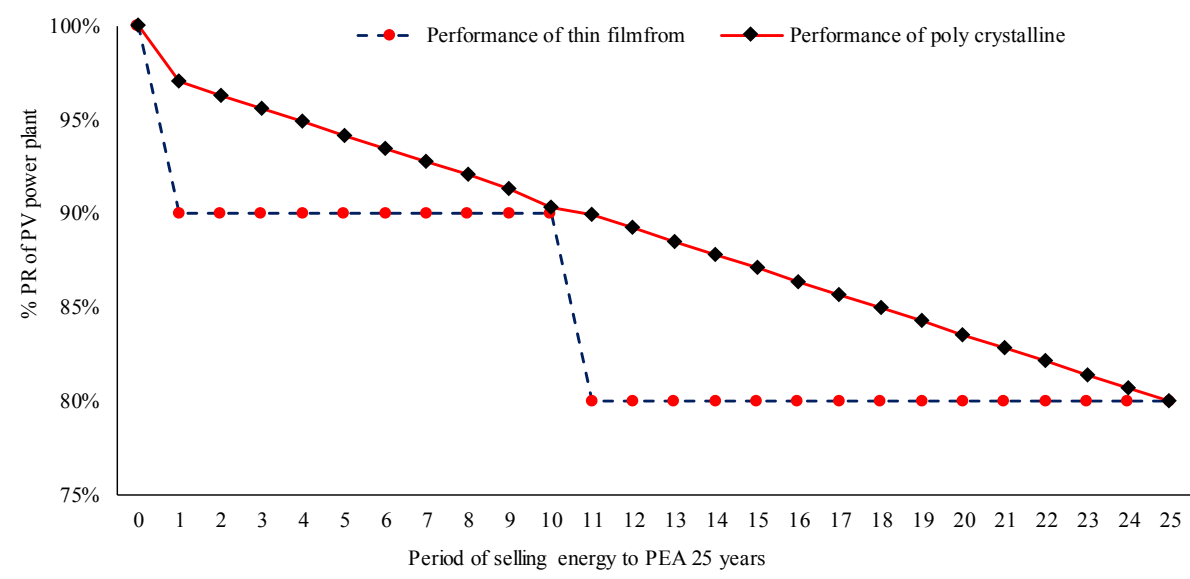

Fig. 7. PV performance of the thin-film PV power plant and the polycrystalline PV power plant

The polycrystalline PV power plant power plants' performance has begun in the first year at $90 \%$ from year 1 , with linear declines of up to $80 \%$ in the $11^{\text {th }}$ year. The thin-film PV power plant's average performance is $85 \%$, and the polycrystalline PV power plant is $89 \%$. The polycrystalline can generate more energy than the thinfilm PV power plant $4 \%$.

\section{Conclusion}

In this paper, two different PV technologies, thin-film and polycrystalline PV, have been chosen for the analysis of performances and economics. The two studied PV power plants have been installed in Prachin Buri province, the central of Thailand. The comparative study of the PV power plant performances has used NPV method in order to determine the performances of the two PV power plants based on PVsyst simulation program and the actual measured data. The thin-film simulation results and the polycrystalline PV panels in 25 years have showed that the thin-film had the energy production of $207,716,850 \mathrm{kWh}$ and the polycrystalline of $211,872,279 \mathrm{kWh}$. The thin-film PV power plant performances are lower than the polycrystalline PV of $1.962 \%$. The comparative analysis based on real data has shown that the energy production of the thin-film PV power plant had 213,803,194 $\mathrm{kWh}$ and the polycrystalline PV has been $210,151,525 \mathrm{kWh}$. From the results, it is evident that the thin-film PV power plant energy production has been higher than the polycrystalline PV power plant by $1.708 \%$. Therefore, from the study and the comparison of two PV technologies based on the actual data it has been revealed that the thin-film PV technology is suitable for installing a PV power plant in the future.

\section{Acknowledgements}

The authors would like to thank the reviewers and editors for their helpful comments that significantly contribute to improving the article. The authors thank the Rajamangala University of Technology Thanyaburi, Thailand, for providing the laboratory and financial support.

\section{References}

[1] Chandanachulaka, N., Khan-ngern, W., Design of Zero Energy Consumption System for Small DC Residential Home Based on Off-Grid PV System, (2018) International Review of Electrical Engineering (IREE), 13 (3), pp. 246-258. doi: https://doi.org/10.15866/iree.v13i3.15205

[2] Prompinit, K., Khomfoi, S., A Battery Energy Storage System Control Technique with Ramp Rate and C-Rate Parameter Consideration for AC Microgrid Applications, (2018) International Review of Electrical Engineering (IREE), 13 (2), pp. 137-148.

doi: https://doi.org/10.15866/iree.v13i2.14160

[3] Khemmook, P., Khomfoi, S., Transient Stability Improvement Using Coordinated Control of Solar PVs and Solid State 
Transformers, (2018) International Review of Electrical Engineering (IREE), 13 (6), pp. 486-494. doi: https://doi.org/10.15866/iree.v13i6.15869

[4] Khemmook, P., Khomfoi, S., Solid State Transformers Using Selective Harmonic Elimination Technique for Solar Farm Applications, (2020) International Review of Electrical Engineering (IREE), 15 (6), pp. 443-455. doi: https://doi.org/10.15866/iree.v15i6.17654

[5] Laraki, M., Hayar, A., New Mathematical Model Based on OFDM Technique for Smart Lighting Systems in Smart City, (2018) International Review of Electrical Engineering (IREE), 13 (3), pp. 213-228. doi: https://doi.org/10.15866/iree.v13i3.14388

[6] Koskela, J., Rautiainen, A., Kallioharju, K., Harsia, P., Järventausta, P., Effect of the Electricity Metering Interval on the Profitability of Domestic Grid-Connected PV Systems and BESSs, (2020) International Review of Electrical Engineering (IREE), 15 (2), pp. 164-173. doi: https://doi.org/10.15866/iree.v15i2.18357

[7] A. Setiawan, Q. H, A. D. Pranadi, C. A. F, and E. A. Setiawan, Determination of Optimal PV Locations and Capacity in Radial Distribution System To Reduce Power Losses, Energy Procedia, vol. 156, pp. 384-390, 2019/01/01/2019.

[8] S. Oliveira-Pinto and J. Stokkermans, Assessment of the potential of different floating solar technologies - Overview and analysis of different case studies, Energy Conversion and Management, vol. 211 , p. $112747,2020 / 05 / 01 / 2020$

[9] N. M. Kumar, R. P. Gupta, M. Mathew, A. Jayakumar, and N. K. Singh, Performance, energy loss, and degradation prediction of roof-integrated crystalline solar PV system installed in Northern India, Case Studies in Thermal Engineering, vol. 13, p. 100409 , 2019/03/01/ 2019

[10] S. S. Bhullar and M. Lalwani, Performance Analysis of 25 MW Grid Connected Solar Photovoltaic Plant in Gujarat, India, in 2018 3rd International Innovative Applications of Computational Intelligence on Power, Energy and Controls with their Impact on Humanity (CIPECH), 2018, pp. 1-6.

[11] A. A. Merrouni, A.-i. Amrani, and A. Mezrhab, Electricity production from large scale PV plants: Benchmarking the potential of Morocco against California, US, Energy Procedia, vol. 119, pp. 346-355, 2017/07/01/2017.

[12] H. I. Dag and M. S. Buker, Performance evaluation and degradation assessment of crystalline silicon based photovoltaic rooftop technologies under outdoor conditions, Renewable Energy, vol. 156, pp. 1292-1300, 2020/08/01/ 2020.

[13] C. Hajjaj et al., Degradation and performance analysis of a monocrystalline PV system without EVA encapsulating in semiarid climate, Heliyon, vol. 6, no. 6, p. e04079, 2020/06/01/ 2020.

[14] A. Yalawar and S. Nayak, Evaluation of Performance Parameters and Economic Analysis of 1MW Grid Connected Solar PV Plant, in 2018 4th International Conference for Convergence in Technology (I2CT), 2018, pp. 1-5.

[15] S.-V. Oprea and A. Bâra, Ultra-short-term forecasting for photovoltaic power plants and real-time key performance indicators analysis with big data solutions. Two case studies - PV Agigea and PV Giurgiu located in Romania, Computers in Industry, vol. 120, p. 103230, 2020/09/01/ 2020.

[16] International Electrotechnical Commission, Photovotaic system performance monitoring - Guideline for measurement, data exchange and analysis IEC 61724, IEC standard, 1998.

[17] Location of solar PV power plant study at HuaWa, Si Maha Phot District, Prachin Buri province https://www.google.com/maps/place/

[18] Yazaki technical data $2^{\text {nd }}$ edition book Technical data for electric wires and cable, publication : $2^{\text {nd }}$ Edition October 2018

[19] Specification of PV Module, www.sharp.eu/solar date : 7/6/2019

[20] JAsolar datasheet http://www.solardesigntool.com/components/module-panelsolar/JA-Solar/3636/JAP6-72-310-3BB/specification-datasheet.html

[21] OperationManual SG500MX PV Grid-Connected Inverter, www.enfsolar.com/pv/inverter-datasheet/10205 date:7/6/2019

[22] QTC Transformer, "QTC product catalog" [accessed:10,5,2019]. Available: https://qtc-energy.com/download/?lang=th
[23] André Mermoud and Bruno Wittmer, PVSYST USER'S MANUAL PVsyst6, PVSYST SA - Route du Bois-de-Bay 107 1242 Satigny - Switzerland www.pvsyst.com date: January 2014.

[24] A. Del Pizzo, L. P. Di Noia and S. Meo, Super twisting sliding mode control of smart-inverters grid-connected for PV applications, 2017 IEEE 6th International Conference on Renewable Energy Research and Applications (ICRERA), 2017, pp. 793-796. doi: 10.1109/ICRERA.2017.8191168

[25] Simolin, T., Rautiainen, A., Koskela, J., Järventausta, P., Control of EV Charging and BESS to Reduce Peak Powers in Domestic Real Estate, (2019) International Review of Electrical Engineering (IREE), 14 (1), pp. 1-7. doi: https://doi.org/10.15866/iree.v14i1.16034

\section{Authors' information}

Rajamangala University of Technology Thanyaburi (RMUTT), Thailand.

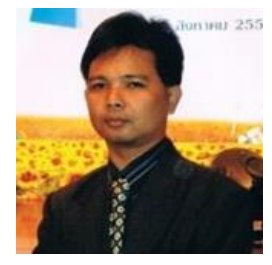

Rungphet Kongnok, Ph.D. student in Electrical Engineering, Faculty of Engineering, Rajamangala University of Technology Thanyaburi (RMUTT), Thailand, and work at Electrical Engineering, Faculty of Engineering, Rajamangala University of Technology Isan (RMUTI), Thailand, the research interests are PV, Energy Management and Renewable Energy.

E-mail: rungphet_k@mail.rmutt.ac.th

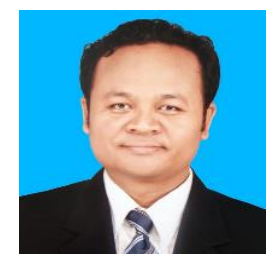

Boonyang Plangklang, Assoc. Prof. Dr.-Ing, at Electrical Engineering, Faculty of Engineering, Rajamangala University of Technology Thanyaburi (RMUTT), RMUTT, Thailand, the research interests are Electrical Power System, Energy Management and Renewable Energy. E-mail: boonyang.p@en.rmutt.ac.th 